\section{Factors associated with time interval between the onset of symptoms and first medical visit in women with breast cancer}

\author{
Fatores associados com o intervalo entre o início \\ de sintomas e a primeira consulta médica entre \\ mulheres com câncer de mama
}

\section{Factores asociados al intervalo de tiempo entre la aparición de síntomas y la primera visita médica de mujeres con cáncer de mama}

Ângela Ferreira Barros 1,2

Cristiane Murta-Nascimento 1

Carlos Henrique de Abdon 3

Daniela Nunes Nogueira 4

Emenny Line Cardoso Lopes 2

Adriano Dias 1

doi: 10.1590/0102-311X00011919

\begin{abstract}
Women presenting with advanced breast cancer tumors are common in Brazil. Little is known about factors contributing to the delay in seeking care. The aim of this study was to identify factors associated with longer time intervals between the onset of breast cancer symptoms and the first medical visit in the Federal District, Brazil. The analysis included 444 symptomatic women with incident breast cancer, interviewed between September, 2012 and September, 2014, during their admission for breast cancer treatment in nine public hospitals in the Federal District. Patients with metastatic disease at diagnosis were not included in this study. The outcome was time interval between symptom onset and the first medical visit, whether $>90$ (34\% of patients) or $\leq 90$ days. Logistic regression was used to estimate odds ratios (OR) and 95\% confidence intervals (95\%CI). In the multivariate analysis, the $>90$ day interval was significantly associated with patients not performing mammography and/or breast ultrasound in the two years prior to breast cancer diagnosis $(\mathrm{OR}=1.97 ; 95 \% \mathrm{CI}: 1.26-3.08)$, and with more advanced stages $(O R=1.72 ; 95 \% C I: 1.10-2.72)$. Furthermore, there was a lower chance of delay in patients with higher levels of education $(\mathrm{OR}=0.95$; 95\% CI: 0.910.99). A relatively high proportion of breast cancer patients in the Brazilian Federal District experienced delay to attend the first medical consultation after the symptoms onset. Increasing breast cancer awareness, especially among women with low educational levels and those not participating in mammography screening programs could contribute to reduce this delay.
\end{abstract}

Breast Neoplasms; Health Services Accessibility; Mammography

\author{
Correspondence \\ A. F. Barros \\ Escola Superior de Ciências da Saúde. \\ SMHN quadra 3, conjunto A, bloco 1, Edifício Fepecs, Brasília, \\ DF 70710-907, Brasil. \\ anbarros@yahoo.com.br \\ 1 Programa de Pós-graduação em Saúde Coletiva, Universidade \\ Estadual Paulista "Júlio de Mesquita Filho", Botucatu, Brasil. \\ 2 Escola Superior de Ciências da Saúde, Brasília, Brasil. \\ 3 Secretaria de Estado de Saúde do Distrito Federal, Brasília, \\ Brasil. \\ 4 Centro Universitário do Distrito Federal, Brasília, Brasil.
}




\section{Introduction}

Breast cancer is the most frequent malignant tumor in women in most countries worldwide. It is the leading cause of death from cancer in women of low and medium Human Development Index countries, where it represents $14.9 \%$ of all cancer deaths 1 . In Brazil, this neoplasm is the most common malignancy in women after non-melanoma skin cancer. The frequency of new cases of breast cancer is also high in the Federal District. It was estimated that 1,020 new cases of breast cancer would be detected there during 2018, which represents the fifth highest incidence rate (62.1 cases per 100,000 women) in Brazil 2.

The mortality rate of breast cancer has been increasing in Brazil ${ }^{3}$ and actions to control this cancer, as proposed by the Brazilian National Cancer Institute (INCA), consist in improvements in both early disease detection and prompt treatment ${ }^{4}$. For early detection, it is important to promote breast cancer screening among the target population and quick identification of breast cancer signs and symptoms by women and/or health professionals, as well as to improve access to health services for diagnosis and treatment 5. However, previous studies in Brazil have shown that women present limited knowledge about some breast cancer signs and symptoms 6,7 and many of them do not routinely undergo mammography screening 8 . These weak points, besides limitations in health services access, may lead women to take longer to attend a first medical visit after identifying any breast alteration suggestive of cancer.

The interval prior to the first consultation includes the time interval between the detection or awareness of a body change defined as "appraisal time" and the time interval of perceiving a reason to talk about the symptoms with a health professional at the first consultation, defined as "help-seeking interval" 9. In the Brazilian context, it is believed that the "appraisal time" and "help-seeking interval" are more relevant than difficulty to obtain the first medical consultation given a national study showing that $97.6 \%$ of the interviewees obtained a medical appointment on their first attempt 10 .

Previous studies suggested that longer time intervals between the onset of symptoms and the first health care visit were associated with older age, lower educational level and lower family income 11,12, but few of such studies were performed in Brazil 13,14, which limits the understanding of such factors regarding the breast cancer in our country.

Based on the above considerations, the aim of this study was to investigate the time interval between the onset of suggestive symptoms of breast cancer and the first medical visit. We further investigated which factors were associated to longer intervals.

\section{Material and methods}

This cross-sectional study started with 600 incident breast cancer patients hospitalized for breast cancer treatment in nine public hospitals of the Federal District, Brazil. Patients with metastatic disease identified before treatment were not included in the study. Data collection was carried out between September 2012 and September 2014. All women were interviewed using a structured questionnaire. Clinical data was retrieved from hospital records and a total of 444 (74\%) consecutive symptomatic women at the first medical visit were included in the analysis, disregarding refusals.

Sample size calculation was based on the estimation that 1,800 new breast cancer cases would be diagnosed in the Federal District during the period of data collection 15. We considered that $40 \%$ of these cases would be treated in private services (Brazilian National Agency for Supplementary Health. http://www.ans.gov.br/anstabnet/cgi-bin/dh?dados/tabnet_tx.def, accessed on 04/Dec/2014) and the time interval between the onset of symptoms and the first medical consultation would exceed 90 days in $30 \%$ of cases 14 .

The variable of interest was the self-referred time interval between the onset of the suggestive symptom of breast cancer and the date of the first medical visit. This variable was dichotomized $-\leq 90$ days and > 90 days - as this was the cut-off point used in other studies 11,16,17,18. The presence of a palpable lump, skin and/or nipple retraction, hyperemia, bulging, abscess or pain in the breast, ulceration, nipple discharge, change in breast size, and the presence of axillary nodules were considered signs/ 
symptoms. The first medical visit was defined as the moment when the patient was first examined due to her complaint regarding the breast.

Other variables were considered, such as patient sociodemographic characteristics (age, marital status, place of residence, educational level, and average family income), family history of breast cancer, periodicity of breast self-examination, date of last mammography and/or breast ultrasound before diagnosis, date of last clinical breast examination before diagnosis, and stages grouped according to the sixth edition of the TNM Classification of Malignant Tumors 20 . Family income per month was expressed in US dollars (1 USD $=2.7$ BRL on December 31, 2014).

The descriptive analysis estimates frequencies for categorical variables and measuring central tendency and dispersion for continuous variables - mean and standard deviation (SD) or median and range. Some variable categories were abandoned for the few cases. Bivariate and multiple logistic regression models were performed. Variables that showed $p$-value $\leq 0.25$ in the bivariate analysis were tested in the multiple model 20 by a stepwise forward method, and remained in the model when p-value $<0.05$. The IBM SPSS Statistics v.20.0 software (https://www.ibm.com/) was used for the analysis.

This study was approved by the Ethics Research Committee of the Health Sciences Teaching and Research Foundation, Federal District Health State Department (Ethics Approval n. 99,313) as recommended by Resolution n. 196/1996 of the Brazilian National Health Council. All participants signed an informed consent form before the interview.

\section{Results}

Out of the 444 women included in this analysis, the mean age at diagnosis was 52.3 years $( \pm 12.8)$ and the most frequent age group was 50 to 69 years (Table 1). The following characteristics were more prevalent: being married or living in a stable union and dwelling in the Federal District. The mean number of schooling time was 7.8 years $( \pm 4.7)$ and the average family income was USD 502.22 (ranging between USD 25.90 and 12,963.00).

The time interval between the onset of suggestive signs/symptoms of breast cancer and the first medical visit showed a median of 39 days (ranging between 0 and 1,857 days), with $34 \%$ occurring up to 90 days.

In both bivariate (Table 2) and multiple regression (Table 3) analyses, the variables that showed a statistically significant association with a longer interval ( $>90$ days) were patients not performing mammography and/or breast ultrasound in the two years prior to breast cancer diagnosis $(\mathrm{OR}=1.97$; 95\%CI: 1.26-3.08), and with more advanced stages ( $\mathrm{OR}=1.72$; 95\%CI: 1.10-2.72). Furthermore, there was a lower chance of delay in patients with higher levels of education $(\mathrm{OR}=0.95 ; 95 \% \mathrm{CI}$ : 0.91-0.99).

\section{Discussion}

Our results reveal that one third of the sample (34\%) had a considerable time interval between the onset of symptoms and the first medical consultation. Three variables were associated with this delay: lower educational level, not undergoing mammography and/or breast ultrasound in the two years prior to the diagnosis, and cases diagnosed at more advanced stages.

The median interval between the onset of signs/symptoms and the first medical visit observed i.e., 39 days - was higher than reported in previous studies in Brazil 13,14. Over one-third showed an interval exceeding 90 days, which is longer than in other countries 16,21,22,23. Although methodological differences between studies and different characteristics of health services among countries hinder the results comparison, we consider that devising actions to reduce this interval in the Brazilian scenario should be a priority, given that longer intervals are associated with lower survival rates of breast cancer 24 .

To reduce this interval, it would be important to remember that women with lower educational levels were more susceptible to have longer intervals, which is consistent with results from other studies $21,25,26$. Lower educational levels are also associated with lower levels of awareness and recognition of breast cancer warning signs 27,28 . 
Table 1

Characteristics of 444 symptomatic women with breast cancer treated at public hospitals in the Brazilian Federal District between September 2012 and September 2014.

\begin{tabular}{|c|c|c|}
\hline Characteristics & $\mathbf{n}$ & $\%$ \\
\hline \multicolumn{3}{|l|}{ Age group (years) } \\
\hline$<40$ & 81 & 18.2 \\
\hline $40-49$ & 120 & 27.0 \\
\hline $50-69$ & 195 & 43.9 \\
\hline$>70$ & 48 & 10.8 \\
\hline \multicolumn{3}{|l|}{ Place of residence } \\
\hline Federal District & 281 & 63.3 \\
\hline Other & 163 & 36.7 \\
\hline \multicolumn{3}{|l|}{ Marital status } \\
\hline Single & 98 & 22.1 \\
\hline Married or living with a partner & 233 & 52.5 \\
\hline Divorced & 57 & 12.8 \\
\hline Widow & 56 & 12.6 \\
\hline \multicolumn{3}{|l|}{ Family income (USD per month) * } \\
\hline$>502.20$ & 230 & 53.1 \\
\hline$\leq 502.20$ & 203 & 46.9 \\
\hline Years of schooling & \multicolumn{2}{|c|}{ Mean 7.8 years $(\mathrm{SD}=4.7)$} \\
\hline \multicolumn{3}{|l|}{ Family history of breast cancer } \\
\hline No & 323 & 72.7 \\
\hline Yes & 121 & 27.3 \\
\hline First-degree relative & 45 & 37.2 \\
\hline Second-degree relative & 76 & 62.8 \\
\hline \multicolumn{3}{|l|}{ Breast self-examination periodicity } \\
\hline Once a month & 212 & 47.7 \\
\hline Less frequent & 232 & 52.3 \\
\hline \multicolumn{3}{|c|}{ Mammography and/or breast ultrasound periodicity ** } \\
\hline$\leq 2$ years & 168 & 39.3 \\
\hline$>2$ years & 93 & 21.8 \\
\hline Not performed before & 166 & 38.9 \\
\hline \multicolumn{3}{|c|}{ Clinical breast examination periodicity *** } \\
\hline$\leq 1$ year & 158 & 37.5 \\
\hline$>1$ year & 193 & 45.8 \\
\hline Not performed before & 70 & 16.6 \\
\hline \multicolumn{3}{|l|}{ Stage group } \\
\hline $0-$ IIA & 156 & 35.1 \\
\hline IIB-IIIC & 288 & 64.9 \\
\hline
\end{tabular}

SD: standard deviation.

* Information available for 433 patients;

** Information available for 427 patients;

*** Information available for 421 patients. 
Table 2

Bivariate analysis. Factors associated with longer time interval (> 90 days) between onset of breast cancer symptoms and first medical visit and associated factors.

\begin{tabular}{|c|c|c|c|c|c|}
\hline \multirow[t]{2}{*}{ Characteristics } & \multirow[t]{2}{*}{ Total } & \multicolumn{2}{|c|}{$\begin{array}{l}\text { Interval between symptom } \\
\text { and first visit }>90 \text { days }\end{array}$} & \multirow[t]{2}{*}{ Crude OR } & \multirow[t]{2}{*}{$95 \% \mathrm{Cl}$} \\
\hline & & $\mathbf{n}$ & $\%$ & & \\
\hline \multicolumn{6}{|l|}{ Age group (years) } \\
\hline$<50$ & 201 & 67 & 33.3 & 1.00 & - \\
\hline$\geq 50$ & 243 & 86 & 35.4 & 1.10 & $0.74-1.62$ \\
\hline \multicolumn{6}{|l|}{ Place of residence } \\
\hline Federal District & 281 & 98 & 35.9 & 1.00 & - \\
\hline Other & 163 & 52 & 31.9 & 0.84 & $0.55-1.26$ \\
\hline \multicolumn{6}{|l|}{ Marital status } \\
\hline With a partner & 233 & 72 & 32.6 & 1.00 & - \\
\hline Without a partner & 211 & 77 & 36.5 & 1.19 & $0.80-1.76$ \\
\hline \multicolumn{6}{|l|}{ Family income (USD per month) } \\
\hline$>502.20$ & 203 & 65 & 32.0 & 1.00 & - \\
\hline$\leq 502.20$ & 230 & 84 & 36.1 & 1.20 & $0.80-1.79$ \\
\hline Years of schooling & & & & 0.95 & 0.91-0.99 \\
\hline \multicolumn{6}{|l|}{ Family history of breast cancer } \\
\hline Yes & 121 & 37 & 30.6 & 1.00 & - \\
\hline No & 323 & 113 & 35.9 & 1.27 & 0.81-1.99 \\
\hline \multicolumn{6}{|c|}{ Breast self-examination performed at least once a month } \\
\hline Yes & 212 & 71 & 33.5 & 1.00 & - \\
\hline No & 232 & 79 & 34.1 & 1.01 & $0.68-1.49$ \\
\hline \multicolumn{6}{|c|}{ Mammography and/or breast ultrasound periodicity } \\
\hline$\leq 2$ years & 168 & 39 & 23.2 & 1.00 & - \\
\hline$>2$ years or never performed & 259 & 103 & 40.5 & 2.26 & $1.46-3.49$ \\
\hline \multicolumn{6}{|c|}{ Clinical breast examination periodicity } \\
\hline$\leq 1$ year & 158 & 44 & 28.5 & 1.00 & - \\
\hline$>1$ year & 263 & 95 & 36.1 & 1.42 & $0.93-2.18$ \\
\hline \multicolumn{6}{|l|}{ Stage group } \\
\hline $0-I I A$ & 156 & 38 & 25.6 & 1.00 & - \\
\hline$\|B-\| I C$ & 288 & 112 & 39.2 & 1.87 & $1.25-2.88$ \\
\hline
\end{tabular}

95\%Cl: 95\% confidence interval; OR: odds ratio.

Table 3

Multivariate analysis. Factors associated with longer time interval ( $>90$ days) between onset of breast cancer symptoms and first medical visit and associated factors.

\begin{tabular}{lccc}
\hline Characteristics & Adjusted OR & $\mathbf{9 5 \% C l}$ & p-value \\
\hline $\begin{array}{l}\text { Years of schooling } \\
\text { Mammography and/or breast ultrasound periodicity }\end{array}$ & 0.95 & $0.91-0.99$ & 0.042 \\
$\quad$ 2 years & 1.00 & - & \\
$\quad$ 2 years or never performed & 1.97 & $1.26-3.08$ & 0.003 \\
Stage group & & & \\
$\quad$ O-IIA & 1.00 & - & 0.02 \\
IIB-IIIC & 1.72 & $1.10-2.72$ & \\
\hline
\end{tabular}

95\%Cl: 95\% confidence interval; OR: odds ratio. 
Furthermore, knowledge about breast cancer signs/symptoms among the Brazilian population is limited. A recent study including 478 women aged 40 or older in the city of Rio Branco, in Northern Brazil, reported that women were aware of some signs/symptoms such as lumps, nipple discharge, and breast discomfort. However, most of the sample did not identify nipple retraction, redness of breast skin and/or nipple discharge as breast cancer signs/symptoms 7 . The difficulty in recognizing breast cancer warning signs may have resulted in longer intervals prior to the first consultation.

Moreover, note that the perceived barriers regarding access to health services are more frequently observed among people with worse socioeconomic conditions, in addition to previous experience and judgment regarding health services that may lead to avoidable delays and late diagnosis 29,30 .

Access to outpatient secondary services such as mammography is limited in Brazil 31. An increase in the rate of mammography screening coverage among the target population should contribute to an earlier diagnosis. Although the INCA advises biennial mammography screening for women between 50 and 69 years 4 , there is no population-based breast cancer screening program in the country and women only have access to screening strategies opportunistically 8 . Besides, there is a reason to believe that mammography performance contributes to breast cancer awareness among patients and health professionals. An association was observed in other studies between delay at attending and patients not undergoing mammography or breast ultrasound 17,21,23,32.

Breast self-examination and clinical breast examination periodicity were not associated with a longer time interval to attend the first medical visit constrasting with previous studies 21,32,33. Moreover, these practices are not recommended for breast cancer screening on recent national directive 4 .

Finally, there was an association of more advanced stages with delay to attend the first medical consultation as in other studies 13,16,34. This association was found in both bivariate and multivariable analyses, which points to the importance of this delay regarding the disease outcome. Women with advanced breast cancer tumors at medical appointment are common in Brazil, with more than $70 \%$ of the tumors diagnosed at stage II or higher 35. This highlights the importance of speeding up the first medical visit after the onset of symptoms by improving breast cancer awareness to detect the disease at earlier stages 36 .

No association was observed between the delay to attend the first medical visit after the onset of symptoms and age, marital status, family history of cancer, income, or distance between place of residence and health care facilities, unlike what was previously reported 16,18,21,37. This inconsistency may result of various circumstances: methodological differences; the fact that these events depend on the sociocultural context 38 ; insufficient research about these aspects related with delay 39 .

This is one of the largest studies performed in Brazil focusing on this issue, but it has some limitations. Patients with metastatic disease at diagnosis were not included in our study and this may have decreased the delay interval. Moreover, patients might not accurately remember when certain events occurred in their lives, which might translate into some memory bias; to minimize this risk, this study included only incident breast cancer cases. Furthermore, there is a possibility that some patients did not report the real time interval to avoid shame or embarrassment, as previously reported 24 .

In conclusion, in a relatively high proportion of breast cancer patients in the Federal District, the first medical visit occurs long after the onset of symptoms. Thus, increasing breast cancer awareness, especially among women with low educational levels and those not participating in mammography screening programs could contribute to reduce this delay. 


\section{Contributors}

All authors contributed in all stages of article production.

\section{Additional informations}

ORCID: Ângela Ferreira Barros (0000-0003-01944196); Cristiane Murta-Nascimento (0000-00018686-1079); Carlos Henrique de Abdon (00000001-6049-4362); Daniela Nunes Nogueira (00000001-5891-9181); Emenny Line Cardoso Lopes (0000-0002-2808-6278); Adriano Dias (0000-00016895-372X).

\section{References}

1. Bray F, Ferlay J, Soerjomataram I, Siegel RL, Torre LA, Jemal A. Global cancer statistics 2018: GLOBOCAN estimates of incidence and mortality worldwide for 36 cancers in 185 countries. CA Cancer J Clin 2018; 68:394-424.

2. Instituto Nacional de Câncer José Alencar Gomes da Silva. Estimativa 2018: incidência de câncer no Brasil. Rio de Janeiro: Instituto $\mathrm{Na}$ cional de Câncer José Alencar Gomes da Silva; 2017.

3. Kluthcovsky ACGC, Faria TNP, Carneiro FH, Strona R. Female breast cancer mortality in Brazil and its regions. Rev Assoc Med Bras 2014; 60:387-93.

4. Migowski A, Azevedo e Silva G, Dias MBK, Diz MDPE, Sant'Ana DR, Nadanovsky P. Guidelines for early detection of breast cancer in Brazil. II - New national recommendations, main evidence, and controversies. Cad Saúde Pública 2018; 34:e00074817.

5. Corbex M, Burton R, Sancho-Garnier H. Breast cancer early detection methods for low and middle income countries, a review of the evidence. Breast 2012; 21:428-34.

6. Santos GD, Chubaci RY. O conhecimento sobre o câncer de mama e a mamografia das mulheres idosas frequentadoras de centros de convivência em São Paulo (SP, Brasil). Ciênc Saúde Colet 2011; 16:2533-40.

7. Schilling MP, Silva IF, Opitz SP, Borges MF, Koifman S, Koifman RJ. Breast cancer awareness among women in Western Amazon: a population based cross-sectional study. Asian Pac J Cancer Prev 2017; 18:847-56.

\section{Acknowledgments}

We would like to thank Mastology Unit of the Brasília University Hospital, Federal District Base Hospital, and the Oncology Service of the Taguatinga Regional Hospital, Brasília (Federal District, Brazil). This study was supported by the Higher Education School of Health Sciences (ESCS).

8. Bezerra HS, Melo TFV, Barbosa JV, Feitosa EELC, Sousa LCM. Evaluation of access to mammographies in Brazil and socioeconomic indicators: a space study. Rev Gaúch Enferm 2018; 39:e20180014.

9. Weller D, Vedsted P, Rubin G, Walter FM, Emery J, Scott S, et al. The Aarhus statement: improving design and reporting of studies on early cancer diagnosis. Br J Cancer 2012; 106:1262-7.

10. Szwarcwald CL, Damacena GN, Souza Júnior PRB, Almeida WS, Malta DC. Perception of the Brazilian population on medical health care. Brazil, 2013. Ciênc Saúde Colet 2016; 21:339-49.

11. Sharma K, Costas A, Damuse R, HamiltongPierre J, Pyda J, Ong CT, et al. The Haiti Breast Cancer Initiative: initial findings and analysis of barriers-to-care delaying patient presentation. J Oncol 2013; 2013:206367.

12. Yau TK, Choi CW, Ng E, Yeung R, Soong IS, Lee AWM. Delayed presentation of symptomatic breast cancers in Hong Kong: experience in a public cancer center. Hong Kong Med J 2010; 16:373-7.

13. Rezende MCR, Koch HA, Figueiredo JA, Thuler LCS. Factors leading to delay in obtaining definitive diagnosis of suspicious lesions for breast cancer in a dedicated health unit in Rio de Janeiro. Rev Bras Ginecol Obstet 2009; 31:75-81. 
14. Barros AF, Uemura G, Macedo JLS. Interval for access to treatment for breast cancer in the Federal District, Brazil. Rev Bras Ginecol Obstet 2013; 35:458-63.

15. Instituto Nacional de Câncer José Alencar Gomes da Silva. Estimativa 2012: incidência de câncer no Brasil. Rio de Janeiro: Instituto $\mathrm{Na}$ cional de Câncer José Alencar Gomes da Silva; 2011.

16. Piñeros M, Sanchez R, Cendales R, Perry F, Ocampo R. Patient delay among Colombian women with breast cancer. Salud Pública Méx 2009; 51:372-80.

17. Ghazali SM, Othman Z, Cheong KC, Hock AK, Mahiyuddin WRW, Kamaluddin MA, et al. Non-practice of breast self examination and marital status are associated with delayed presentation with breast cancer. Asian Pac J Cancer Prev 2013; 14:1141-5.

18. Memon ZA, Shaikh AN, Rizwan S, Sardar MB. Reasons for patient's delay in diagnosis of breast carcinoma in Pakistan. Asian Pac J Cancer Prev 2013; 14:7409-14.

19. Instituto Nacional de Câncer. TNM: classificação de tumores malignos. 6a $\mathrm{Ed}$. Rio de Janeiro: Instituto Nacional de Câncer; 2004.

20. Hosmer Jr. DW, Lemeshow S. Applied logistic regression. 2nd Ed. Hoboken: John Wiley \& Sons; 2005.

21. Ozmen V, Boylu S, Ok E, Canturk NZ, Celik V, Kapkac M, et al. Factors affecting breast cancer treatment delay in Turkey: a study from Turkish Federation of Breast Diseases Societies. Eur J Public Health 2015; 25:9-14.

22. Hansen RP, Vedsted P, Sokolowski I, Søndergaard J, Olesen F. Time intervals from first symptom to treatment of cancer: a cohort study of 2,212 newly diagnosed cancer patients. BMC Health Serv Res 2011; 11:284.

23. Innos K, Padrik P, Valvere V, Eelma E, Kütner $\mathrm{R}$, Lehtsaar J, et al. Identifying women at risk for delayed presentation of breast cancer: a cross-sectional study in Estonia. BMC Public Health 2013; 13:947.

24. Richards MA, Westcombe AM, Love SB, Littlejohns P, Ramirez AJ. Influence of delay on survival in patients with breast cancer: a systematic review. Lancet 1999; 353:1119-26.

25. Khan MA, Hanif S, Iqbal S, Shahzad MF, Shafique S, Khan MT. Presentation delay in breast cancer patients and its association with sociodemographic factors in North Pakistan. Chin J Cancer Res 2015; 27:288-93.

26. Stamatovic L, Vasovic S, Trifunovic J, Boskov N, Gajic Z, Parezanovic A, et al. Factors influencing time to seeking medical advice and onset of treatment in women who are diagnosed with breast cancer in Serbia. Psychooncology 2018; 27:576-82.

27. Quaife SL, Forbes LJ, Ramirez AJ, Brain KE, Donnelly C, Simon AE, et al. Recognition of cancer warning signs and anticipated delay in help-seeking in a population sample of adults in the UK. Br J Cancer 2014; 110:12-8.
28. Hvidberg L, Pedersen AF, Wulff CN, Vedsted P. Cancer awareness and socio-economic position: results from a population-based study in Denmark. BMC Cancer 2014; 14:581.

29. Khakbazan Z, Taghipour A, Roudsari RL, Mohammadi E. Help seeking behavior of women with self-discovered breast cancer symptoms: a meta-ethnographic synthesis of patient delay. PLoS One 2014; 9:e110261.

30. McCutchan GM, Wood F, Edwards A, Richards R, Brain KE. Influences of cancer symptom knowledge, beliefs and barriers on cancer symptom presentation in relation to socioeconomic deprivation: a systematic review. BMC Cancer 2015; 15:1000.

31. Tomazelli JG, Silva GA. Breast cancer screening in Brazil: an assessment of supply and use of Brazilian National Health System health care network for the period 2010-2012. Epidemiol Serv Saúde 2017; 26:713-24.

32. Jassem J, Ozmen V, Bacanu F, Drobniene M, Eglitis J, Lakshmaiah KC, et al. Delays in diagnosis and treatment of breast cancer: a multinational analysis. Eur J Public Health 2014; 24:761-7.

33. Romanoff A, Constant TH, Johnson KM, Guadiamos MC, Vega AMB, Zunt J, et al. Association of previous clinical breast examination with reduced delays and earlier-stage breast cancer diagnosis among women in Peru. JAMA Oncol 2017; 3:1563-7.

34. Odongo J, Makumbi T, Kalungi S, Galukande M. Patient delay factors in women presenting with breast cancer in a low income country. BMC Res Notes 2015; 8:467.

35. Abrahão KS, Bergmann A, Aguiar SS, Thuler LCS. Determinants of advanced stage presentation of breast cancer in 87,969 Brazilian women. Maturitas 2015; 82:365-70.

36. Yip CH, Smith RA, Anderson BO, Miller AB, Thomas DB, Ang ES, et al. Guideline implementation for breast healthcare in low- and middle-income countries: early detection resource allocation. Cancer 2008; 113(8 Suppl):2244-56.

37. Thakur NA, Humne AY, Godale LB. Delay in presentation to the hospital and factors affecting it in breast cancer patients attending tertiary care center in Central India. Indian J Cancer 2015; 52:102-5.

38. Freitas AG, Weller M. Patient delays and system delays in breast cancer treatment in developed and developing countries. Ciênc Saúde Colet 2015; 20:3177-89.

39. Webber C, Jiang L, Grunfeld E, Groome PA. Identifying predictors of delayed diagnoses in symptomatic breast cancer: a scoping review. Eur J Cancer Care (Engl) 2017; 26:e12483. 


\section{Resumo}

São comuns no Brasil os casos de mulheres com tumores de mama em estágio avançado ao diagnóstico inicial. Há pouca informação sobre os fatores que contribuem para a demora na busca de atendimento. O estudo teve como objetivo identificar os fatores associados a intervalos mais longos entre o início dos sintomas do câncer de mama e a primeira consulta médica no Distrito Federal, Brasil. A análise incluiu 444 mulheres sintomáticas com diagnóstico de câncer de mama, entrevistadas entre setembro de 2012 e setembro de 2014, durante a internação para o tratamento do câncer em nove hospitais públicos no Distrito Federal. As pacientes com doença metastática ao diagnóstico não foram incluídas no estudo. A variável de desfecho era o intervalo entre o início dos sintomas e a primeira consulta médica, sendo classificada como > 90 dias (34\% das pacientes) ou $\leq 90$ dias. Foi usada regressão logística para estimar os odds ratios $(O R) e$ intervalos de 95\% de confiança (IC95\%). Na análise multivariada, o intervalo de $>90$ dias mostrou associação significativa com a falta de mamografia e/ou de ultrassom mamário nos dois anos anteriores ao diagnóstico de câncer de mama (OR = 1,97; IC95\%: 1,26-3,08), e com estágios mais avançados da doença (OR = 1,72; IC95\%: 1,102,72). Além disso, houve probabilidade menor de demora em pacientes com maior escolaridade (OR = 0,95; IC95\%: 0,91-0,99). Uma proporção relativamente alta de pacientes com câncer de mama no Distrito Federal sofreram demora na primeira consulta médica após o início dos sintomas. Uma maior conscientização sobre câncer de mama, principalmente entre mulheres com menores níveis de escolaridade e aquelas que não participam em programa de rastreamento com mamografia, pode contribuir para a redução dessa demora.

Neoplasias da Mama; Acesso aos Serviços de Saúde; Mamografia

\section{Resumen}

Las mujeres que presentan tumores avanzados de cáncer de mama son comunes en Brasil. Se sabe poco sobre los factores que contribuyen al retraso en la búsqueda de atención. El objetivo de este estudio fue identificar los factores asociados a los intervalos de tiempo más largos entre la aparición de los síntomas de cáncer de pecho y la primera visita médica en el Distrito Federal, Brasil. El análisis incluyó a 444 mujeres con síntomas de cáncer de pecho, que fueron entrevistadas entre septiembre 2012 y septiembre 2014, durante el tratamiento de cáncer de mama en nueve hospitales públicos del Distrito Federal. Pacientes con enfermedad metastásica en el diagnóstico no estuvieron incluidos en este estudio. El resultado fue el intervalo de tiempo entre la aparición de los síntomas y la primera visita médica, si > 90 (34\% de pacientes) o 590 días. La regresión logística se usó para estimar odds ratios (OR) y los intervalos de 95\% de confianza (IC95\%). En el análisis multivariado, los > 90 días de intervalo estuvieron significativamente asociados con pacientes que no se realizaron mamografías y/o ultrasonidos en el pecho en los dos años previos al diagnóstico de cáncer de mama $(O R=$ 1.97; 95\%CI: 1.26-3.08), y en estadios más avanzados $(O R=1.72 ; 95 \% C I: 1.10-2.72)$. Además, hubo una probabilidad más baja de retraso en pacientes con niveles más altos de educación (OR = 0.95; 95\%CI: 0.91-0.99). Una proporción relativamente alta de pacientes con cáncer de pecho en el Distrito Federal sufrieron retrasos para realizar las primeras consultas médicas tras la aparición de los sintomas. El aumento de la concienciación sobre el cáncer de mama, especialmente entre mujeres con bajo nivel educacional y quienes no participaron en programas de mamografías pudieron contribuir a la reducción de este retraso.

Neoplasias de la Mama; Accesibilidad a los Servicios de Salud; Mamografía
Submitted on $21 / \mathrm{Jan} / 2019$

Final version resubmitted on 18/Apr/2019

Approved on 25/Jul/2019 